\title{
Land Resource Management for Sustainability in the Oku-Mbessa Highlands, North West Region, Cameroon
}

\author{
Mbanga Lawrence Akei", Bailack Kevin Mbuh \\ Department of Geography and Planning, The University of Bamenda, Bambili, Cameroon \\ Email address: \\ mbangalaw@yahoo.com (M. L. Akei).mbuhbailack@gmail.com (B. K. Mbuh) \\ ${ }^{*}$ Corresponding author
}

\section{To cite this article:}

Mbanga Lawrence Akei, Bailack Kevin Mbuh. Land Resource Management for Sustainability in the Oku-Mbessa Highlands, North West Region, Cameroon. International Journal of Natural Resource Ecology and Management. Vol. 4, No. 6, 2019, pp. 173-182.

doi: $10.11648 /$ j.jijnrem.20190406.13

Received: September 4, 2019; Accepted: September 29, 2019; Published: October 31, 2019

\begin{abstract}
Land resources constitute one of the most indispensable resources and the ultimate prerequisites for the survival and prosperity of humankind on the earth surface. Management is very indispensible for sustainability and livelihoods of resources and population respectively. The aim of the study is to examine the trends of land resource management, and present the implications on land resource sustainability and livelihoods using Landsat images of 1988, 2000,2007 and 2018 in the Oku-Mbessa Highlands of Cameroon. A historical survey and comparative research designs with mixed qualitative-quantitative research approaches were used to detect the annual rates of land resource cover changes for the periods of 1982 to 1994 , 1995 to 2006 and 2007 to 2018, analysed at spatiotemporal levels. Data was collected from 150 household heads using a semistructured questionnaire. Data was analysed using inferential statistics with the F-ratio Test at a 0.05 critical level and a df of 4 to determine the management trends, sustainable and livelihood patterns ushered. The results reveal the calculated F-ratio values for the three periodical trends of $1.09,1.21$ and 2.05 are higher than the tabulated ratios of $0.36,0.31$ and 0.89 respectively. This indicates that there has been a significant increase in the trends of land resource management. Positive environmental sustainable and livelihood patterns were introduced in the management process. This study recommends the need for the government to improve management security at the grassroots level to forestall the inextricable link between resource management, sustainability and livelihoods in the Oku-Mbessa highlands.
\end{abstract}

Keywords: Land Resources, Stakeholder, Management, Trends, Sustainability, Oku-Mbessa

\section{Introduction}

Land resources (LRs) constitute one of the most indispensable resources and the ultimate prerequisites for the survival and prosperity of humankind on the earth surface. Management is essential since it is the platform on which human activities take place. They provide mankind with living space, raw materials for obtaining satisfaction for material needs and constitute man's biophysical environment. Land is not only useful for rural people who have their livelihoods based in agriculture, but also a basis of wealth and power [1]. Land resource management (LRM) is a knowledge-based procedure that helps integrate land, water, biodiversity and environmental management with implications on resource cover changes, rising food and livelihood demands while sustaining ecosystem services [2].
At this global scale it requires using structural and biological methods with proper planning which enhance the economic (livelihoods) and social status (acquisition) of the people and sustainable exploitation of land resources. Generally therefore, the concept of LRM is a goal aimed at maintaining the earth's biological diversity at the local, national and global levels. This is a holistic process where all the resource species and all stakeholders are considered [3]. This has raised a lot of awareness especially following the Rio Earth Summit which led to the wider application of the sustainable resource utilisation principle. LRM now has become an active and positive intervention as an integral part of economic development [4-5].

Proper land resource management in the developed world is an approach aimed at reversing the trends of land resource degradation and a significant surge in the productivity and 
services of land especially in biodiversity niches, hydrology and carbon sequestration functions of watersheds and landscapes [6]. The EU implores the Green Growth Strategy in LRM which seeks to promote environmentally friendly subsidies, green economy and the management of natural resources that can offer economic growth opportunity for local people [7]. It is done through supporting comprehensive agricultural development programs, sustainable forest and biodiversity projects and conservation programs taking the form of cooperation, regional development schemes and local planning schemes. The financing of natural resources management projects and programs in over sea regions for sustainable resource utilisation is primordial [8].

In the developing world, LRM are the most critical challenges of countries in this region today. The exploitation of high-value natural resources, including oil, gas, minerals and timber has often been cited as a key factor in triggering, escalating or sustaining violent conflicts in this region [9]. The mismanagement of land and land resources is contributing to new conflicts and obstructing the peaceful resolution of existing ones. LRM in this continent is done within the framework of the nexus between natural resources management and conflict management. It uses a multi-actor and multi-level approach in dealing with LRs and conflicts [10]. In China, the "Land Resources Plan" or "Land Use Plan" is the approach where land resources planning and management is to use land resources rationally, coordinate and rationally allocate land use among different sections of the national economy, and to arrange land use for each kind of resource development [11]. Policies and plans here are formulated and implemented in a top-down manner in LRM in this continent, usually failing to address local dynamics and needs and at times even conflicting with local values and customary laws [12].

In Cameroon, the trends of LRM reveal five common phases: The management by customary rights by indigenous communities before the $1800 \mathrm{~s}$; the colonial influence on the development of land tenure systems between 1800s and 1960s; the post-independence development of national laws and policies on land administration and systems which are all decentralised and undertaken in land offices (1960s-1980s) with institutional and legislative reforms taken over the arena of LRM. This is the case of the 1974 village land law governing the acquisition and management of village lands; the coordination among government agencies, military influences, political systems, and regional agencies taking central stage [13]. The last phase is the multi-stakeholder and multi-sectorial involvement especially those directly impacted in LR communities with management taking into consideration ecosystem perspectives [14].

The trends and implications of LRM in the Oku-Mbessa highlands (OMHs) reflect historical injustices marked by poor local management and under representation of indigenous stakeholders from individual, family, quarter, tribal with state and external management with the topbottom approach taking pre-eminence. The aim of this study is to identify the LRM trends and sustainable implications of LRM. The study is based on the premise that there has been a significant increase in the trends of land resource management with positive patterns on resource sustainability and livelihoods in the Oku-Mbessa Highlands.

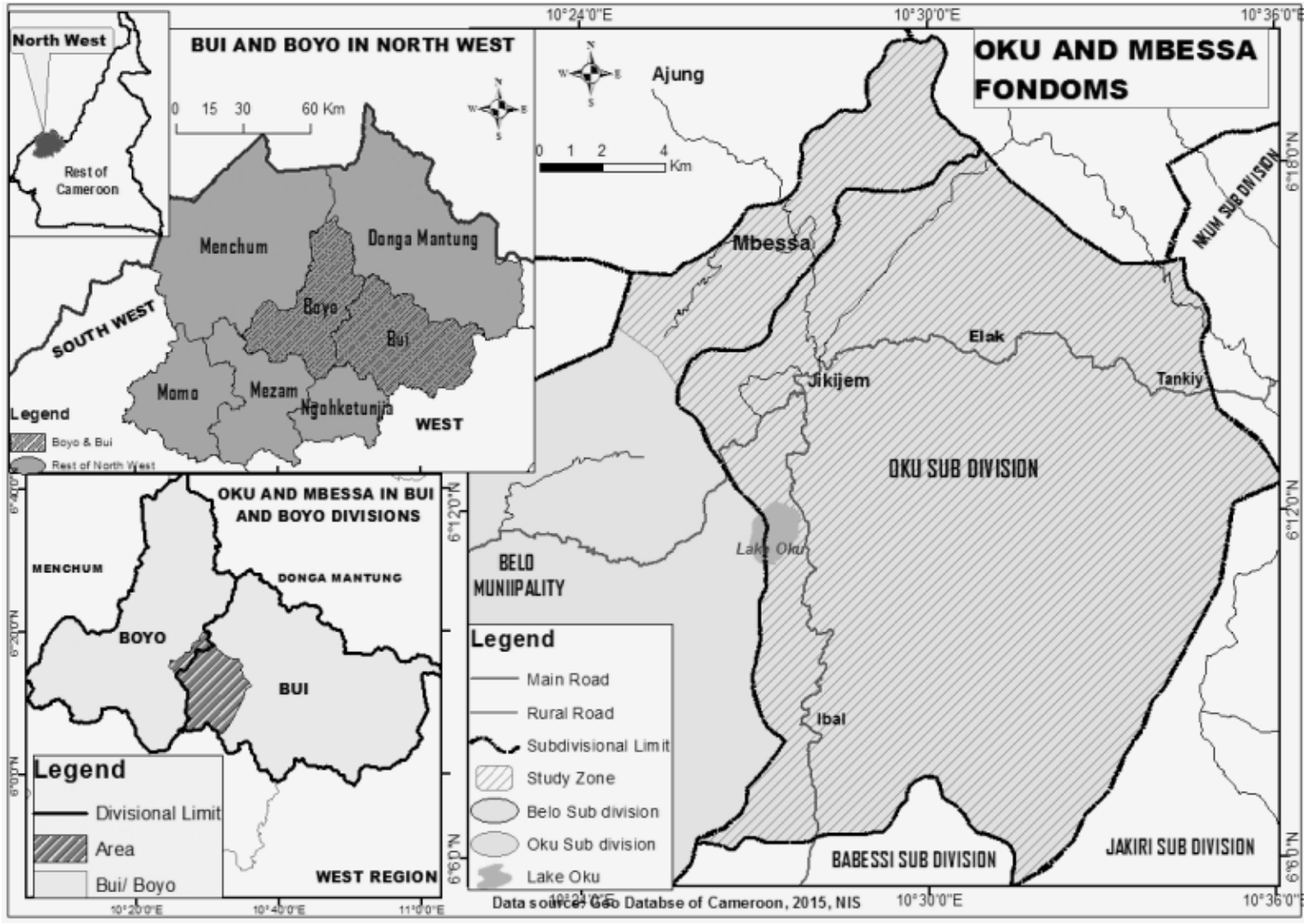

Figure 1. Location of the Oku-Mbessa highlands in Cameroon. 


\section{Materials and Methods}

The study was conducted in the tribes of Oku in Bui Division and Mbessa in Boyo Division of the North West Region of Cameroon. The highland area lies between latitude $6^{\circ} 6^{\prime} 0^{\prime}$ and $6^{0} 16^{\prime} 0^{\prime} \mathrm{N}$ and longitude $10^{\circ} 24^{\prime} 0^{\prime}$ to $10^{\circ} 36^{\prime} 0^{\prime} \mathrm{E}$ (figure 1).

It stretches over $314.17 \mathrm{~km}^{2}$ with Oku covering $276.87 \mathrm{~km}^{2}$ and Mbessa covering $37.29 \mathrm{~km}^{2}$ (Landsat image of March, 2018). The total populations of $\mathrm{Oku}$ and Mbessa were projected 182879 and 19948 inhabitants respectively by 2017 [15].

This study was carried out using a historical survey and comparative research designs with mixed qualitativequantitative research approaches used to detect the annual rates of land resource cover changes for the periods of 1982 to 1994 , 1995 to 2006 and 2007 to 2018 were analysed at spatiotemporal levels. The period from 1982-1994 coincides with the topbottom approach, 1995-2006 concurs with the bottom-top approach and 2007-2018 matches with the participatory approach. The study was conducted in six resource zones (Mbai, Emfveh-miih, Nchiiy, Mbam, Shinga and Mbessa zones) with each ward contributing a representative sample through the use of a purposive random sampling procedure. A semi-structured questionnaire was used for the research and a total of 150 household heads were interviewed. Data was collected from 150 household heads using a semi-structured questionnaire. This was complemented by secondary data obtained from published and unpublished sources such as text books, websites, dissertations and thesis, journals, periodicals, magazines, law and administrative texts. Data was analysed using inferential statistics with the F-ratio Test at a 0.05 critical level and a df of 4 to determine the management trends, sustainability and livelihood patterns ushered.

\section{Results}

\subsection{Trends of Land Resource Management Stakeholders in the Oku/Mbessa Highlands}

The actors involved in LRM in the Oku-Mbessa highlands have evolved and changed in historical times from 1982 to present. According to the population, the numbers of stakeholders have changed in the periodical trends. Field surveys indicate that the actors include indigenous actors (indigenous people, indigenous institutions); state and local development institutions. In the period from 1982-1994 the groups of the stakeholders managing LRs as affirmed by 132 inhabitants from the sample population were less than 5 in number involving mostly indigenous people and the state. This was accounted by the little awareness on the benefits of managing LRs.

The second period from 1995 to 2006 witnessed an increasing trend in the number of stakeholders by $92 \%$ with majority of them falling between the ranges of 6-10 actors involved. A total of 138 inhabitants from the population confirmed that in addition to actors in this first trend, indigenous organisations were added due the increasing awareness of resource benefits its degradation and implications. From 2007-2018, the trend of the number of stakeholders significantly increased. This is established by $144(96 \%)$ inhabitants from the sample population. This $4 \%$ increase was due to the coming in of Non-Governmental Organisations (NGOs) like CAMGEW and SOPISDEW and increased state sectors taking central stage in LRM.

\subsection{Evolution and Change in Land Resource Management Activities from 1982-2018}

Management activities have also evolved and changed. These changes are resulting from the increasing trends in the number of stakeholders. A comparative variations analysis in the two tribes is seen in figure 2.

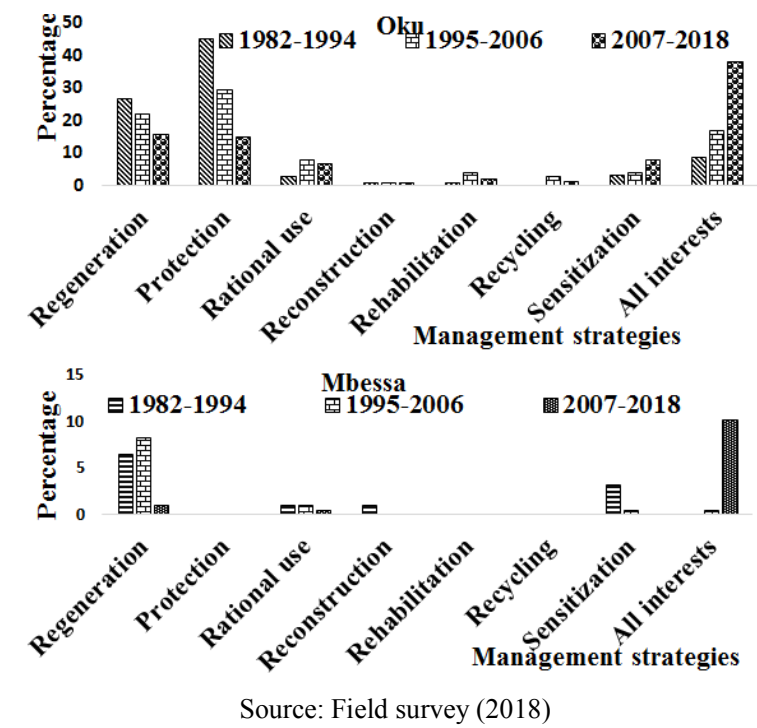

Figure 2. Changes in management activities in Oku and Mbessa from 19822018 .

There has been a general increasing trend in the LRM activities from $10 \%$ to $38.25 \%$ in Oku and $0 \%$ to $10 \%$ in Mbessa and regeneration and protection activities are increasing in Oku that Mbessa where only regeneration is more evident. The period from 1982-1994, protection activities were more dominant in Oku (45\%) while regeneration was highest in Mbessa (8\%).

This is accounted for by the fact that the Kilum forest was declared a reserve in 1987 and this protected the forest from encroachment and bush fires through demarcation and fire tracing. The case of Mbessa with regeneration is because the actions of the traditional institutions like the kwifon and the Njong were highly involved in implementing the regeneration of the forest through tree planting. This is the same trend in the period from 1995-2006 with activities more of protection in Oku and more of regeneration in Mbessa.

Remarkable changes occurred from 2007-2018. During this period, management activities in Oku were more of protection (15\%) compared to only regeneration (less than $2 \%$ ) which was dominant in Mbessa. This is explained by the increasing number of conservationists and NGOs like 
CAMGEW and SOPISDEW which they have been so instrumental in forest regeneration and sensitisation for diversification of livelihoods and resource sustainability since 2012 in Oku (table 1).

Table 1. Activities of NGOs in resource management in Oku from 2012-2018.

\begin{tabular}{|c|c|c|c|c|}
\hline & Year & Number of trees planted & Number of communities sensitised & Number of people sensitised \\
\hline \multirow{7}{*}{ CAMGEW } & 2012 & 7000 & 4 & 147 \\
\hline & 2013 & 10016 & 6 & 98 \\
\hline & 2014 & 20500 & 2 & 654 \\
\hline & 2015 & 25600 & 6 & 201 \\
\hline & 2016 & 13400 & 8 & 212 \\
\hline & 2017 & 3133 & 7 & 233 \\
\hline & 2018 & 7000 & 1 & 57 \\
\hline \multirow{4}{*}{ SOPISDEW } & 2016 & 6500 & 6 & 258 \\
\hline & 2017 & 36000 & 5 & 65 \\
\hline & 2018 & 0 & 2 & 25 \\
\hline & Total & 133449 & 57 & 2399 \\
\hline
\end{tabular}

Source: $[17,18]$

A total of 133449 trees have been planted in the different zones of this area since 2012. CAMGEW has regenerated the vegetation more than SOPISDEW with 86449 trees planted as 47000 trees. CAMGEW has also trained more people and sensitise more communities (34 and 1602 respectively) as against SPOPISDEW with 23 communities and 794 persons sensitised. The dominating activities and successes of CAMGEW are due to many sponsors and early creation in 2007 of the NGO.

\subsection{Analysis of Changes in Land Resource Management Interests from 1982-2018}

Management interests operating alongside with management activities have also evolved and changed driven by the multiple actors and their activities. These changes are presented in figure 3 .

Findings show a general increasing trend in the management interests. This is shown with an increase up from $12.4 \%$ in $1982-1994,30.9 \%$ in $1995-2006$ to $57.6 \%$ in 2007-2018. This general increase in management interests are also reflected in the dominating interest which is livelihood interest with a rate of $40.6 \%$ (1982-1994), $17.97 \%$ (1995-2006) and $9.21 \%$ (2007-2018). This compared to management for political reasons in these periods which is the least.

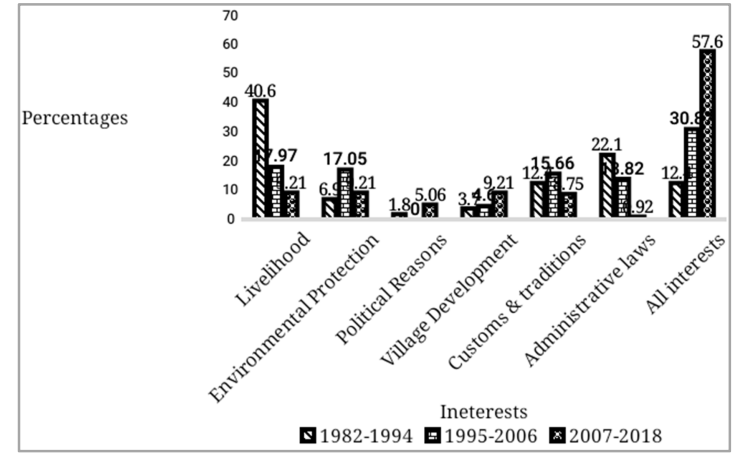

Source: Field survey (2018)

Figure 3. Changes in management interest in the Oku/Mbessa highlands from 1982-2018.

\subsection{Empirical Analysis of Land Resource Management Trends in the Oku-Mbessa Highlands}

The study is based on the premise that there has been a significant increase in the trends of land resource management with positive patterns on resource sustainability and livelihoods in the Oku-Mbessa Highlands. Based on the responses of the population, the F-ratio test was used for this analysis to determine the changes in the trends of land resource management by interest groups (table 2) at a 0.05 critical level at a df of 4 .

Table 2. Determining the trend of land resource management in the Oku/Mbessa highlands.

\begin{tabular}{|c|c|c|c|c|c|c|}
\hline \multicolumn{7}{|l|}{ F-ratio (Anova) } \\
\hline & & Sum of Squares & df & Mean Square & $\mathbf{F}$ & Sig. \\
\hline \multirow{3}{*}{$\begin{array}{l}\text { Major management interests } \\
1982-1994\end{array}$} & Between Groups & 30.055 & 4 & 7.514 & 1.094 & .361 \\
\hline & Within Groups & 1456.259 & 212 & 6.869 & & \\
\hline & Total & 1486.313 & 216 & & & \\
\hline \multirow{3}{*}{$\begin{array}{l}\text { Major management interests } \\
1995-2006\end{array}$} & Between Groups & 35.481 & 4 & 8.870 & 1.210 & .308 \\
\hline & Within Groups & 1554.768 & 212 & 7.334 & & \\
\hline & Total & 1590.249 & 216 & & & \\
\hline \multirow{2}{*}{$\begin{array}{l}\text { Major management interests } \\
2007-2018\end{array}$} & Within Groups & 1459.240 & 212 & 6.883 & & \\
\hline & Total & 1515.770 & 216 & & & \\
\hline
\end{tabular}

Source: Field Survey (2018) 
The calculated F-ratios between the groups for 1982-1994 (1.094); 1995-2006 (1.210) and 2007-2018 (2.053) are more than the tabulated ratios of $0.361,0.308$ and 0.088 respectively. This means that the hypothesis is accepted which states that there has been significant changes in the trends of LRM in this area. This is supported by the general increasing trend of management activities and interests. This increasing trend is explained by the increasing awareness on the importance of the resources, rapid population growth and the demand for more livelihood opportunities.

\subsection{Implications of the Increasing Trend on the Patterns of Land Resource Cover Changes}

The increasing trends of LRM in the in the Oku-Mbessa highlands have brought positive changes in the LRs stocks through land cover changes. These changes are quantified based on the statistics derived from the processing of Landsat images of 1984, 2000, 2007 and 2018 (table 3).

Table 3. Periodical changes of the different land resource quantities from 1982-2018.

\begin{tabular}{lllll}
\hline Resource & $\left.\mathbf{1 9 8 2 - 1 9 9 4} \mathbf{( k m}^{\mathbf{2}}\right)$ & $\mathbf{1 9 9 5 - 2 0 0 6}\left(\mathbf{k m}^{\mathbf{2}}\right)$ & $\mathbf{2 0 0 7}\left(\mathbf{k m}^{\mathbf{2}}\right)$ & $\left.\mathbf{2 0 1 8} \mathbf{( k m}^{\mathbf{2}}\right)$ \\
\hline Built up & 6.8 & 8.29 & 9.01 & 11.37 \\
Cultivable land & 99.61 & 108.24 & 113.24 & 118.19 \\
Forest land & 37.06 & 44.76 & 56.34 & 53.31 \\
Secondary forest & 78.2 & 71 & 68.5 & 67.82 \\
Savannah & 80.14 & 69.46 & 54.81 & 51.42 \\
Water bodies & 12.36 & 12.36 & 12.27 & 12.06 \\
Total & 314.17 & 314.17 & 314.17 & 314.17 \\
\hline
\end{tabular}

Source: Landsat image processing (1984, 2000, 2007 and 2018)

Considering field statistics, $97 \%$ of the population agreed that the total resources stock with a total surface area of $314.17 \mathrm{Km}^{2}$ have been experiencing land resource cover changes in different proportions. The spatial patterns of these temporal changes are presented in figure 4 .

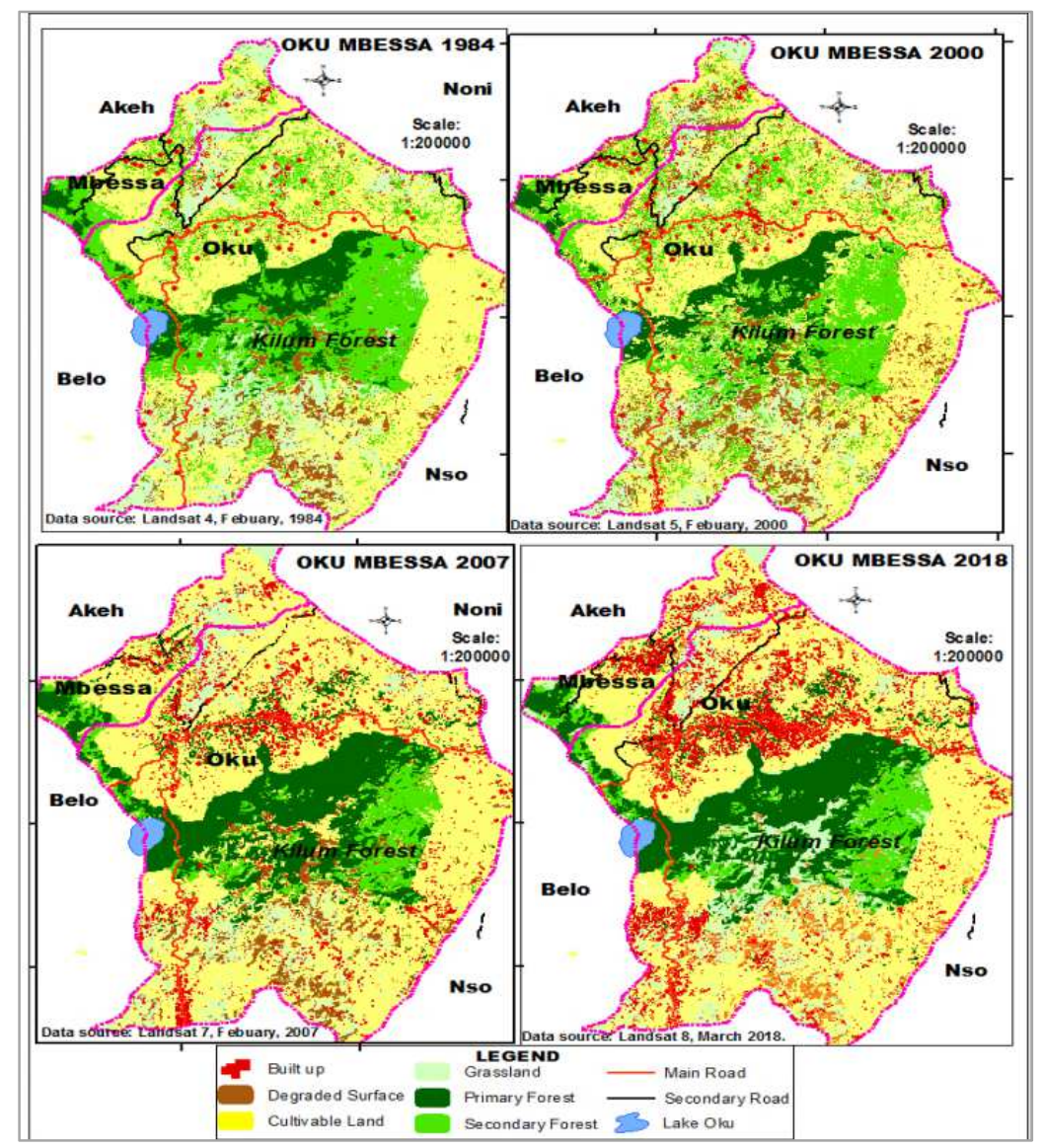

(Source of raw images: US Geological System website at www.usgs.com).

Figure 4. Patterns and changes in land cover for 1982 to 2018. 
From 1982-1994, cultivable land was the highest with $99.61 \mathrm{~km}^{2}$ as compared to the built up area which was made up only of $6.8 \mathrm{~km}^{2}$ (figure 5).

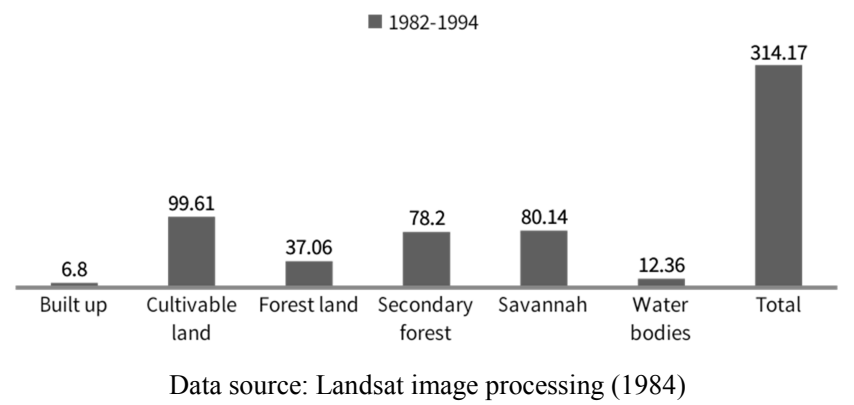

Figure 5. Land resources cover stock for 1982-1994 (figures are in Kilometres square).

The high proportion of cultivable land was due to the high population pressure on the available agricultural land. Agriculture was a major source of livelihood. There was encroachment into the forest zone by farmers to increase the sizes of their farmlands. Reinforcing policies and controlling encroachment were difficult considering that the number of actors to reinforce these were limited during period. These areas had the highest rate of bush fires. The lower proportion of built up area was due to low population densities compared to 2018 .

From 1995-2006, resources degradation was more severe and the rapid loss of the resources was more evident. Build up areas and farming lands increased from $6.8 \mathrm{~km}^{2}$ to $8.29 \mathrm{~km}^{2}(82 \%$ increase $)$ and $99.61 \mathrm{~km}^{2}$ to $108.3 \mathrm{~km}^{2}(92 \%$ increase) respectively at the detriment of the savannah land that dropped from $80.14 \mathrm{~km}^{2}$ to $69.46 \mathrm{~km}^{2}$ (115.4\% decrease) (figure 6).

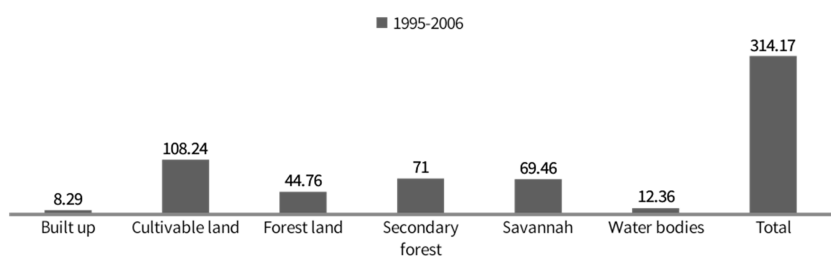

Data source: Landsat image processing (2000)

Figure 6. Land resources cover stock for 1995-2006 (figures are in Kilometres square).

In addition to the reasons accounted for in the first trend, another driver was the fact that the weak action of the traditional institutions in the management of these resources due to suppression from the civil administrators brought in a lot of corruption between the ignorant community executive members and the well-informed state institutions. Encroachment was very high and people transferred their goats into forest. Wet trees were fell down by fuel wood collectors and carvers. In 2007, there were noticeable changes in the LRs cover.

There was a slower increase in built up $\left(0.72 \mathrm{Km}^{2}\right)$ and cultivable land $\left(5 \mathrm{Km}^{2}\right)$. However, there was also a drop in secondary forest from 78.22 in 1984 to $68.5 \mathrm{~km}^{2}$ in 2007 and savannah area from $80.14 \mathrm{~km}^{2}$ in 1984 to $54.81 \mathrm{~km}^{2}$ in 2007 (figure 7).

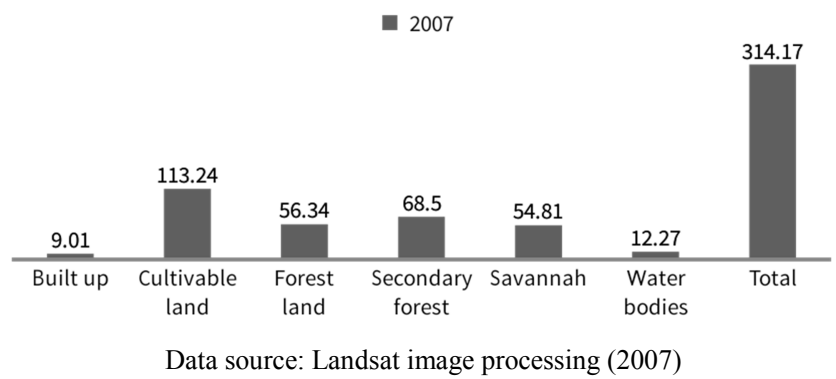

Figure 7. Land resources cover stock for 2007 (figures are in Kilometres square).

The slower increase was due to more restrictions and fight against deforestation for farming and settlement land use. Outstanding in this period is the $19.28 \mathrm{Km}^{2}$ increase in forest land from $37.06 \mathrm{~km}^{2}$ between 1982 and 1994 to $56.34 \mathrm{~km}^{2}$ in 2007. The ugly signatures of environmental and resource degradation were under the lamp light of not only the state and the indigenous stakeholders, but also under the notice of NGOs like Birdlife International, CAMGEW and SOPISDEW and also local development actors like OCDA and MADA.

By 2018, the rate of resource replacement was witnessing an upsurge compared to the first periodical trend. Built up and cultivable land continues to increase at a slower rate from $9.10 \mathrm{~km}^{2}$ in 2007 to $11.37 \mathrm{~km}^{2}$ and $113.24 \mathrm{~km}^{2}$ in 2007 to 118.19 in 2018 respectively. The last land resources cover changes also show resources especially forest marginally decreasing in stock by $3.03 \mathrm{Km}^{2}$. There was also a minor drop in resources like secondary forest, Savannah lands and water bodies (figure 8).

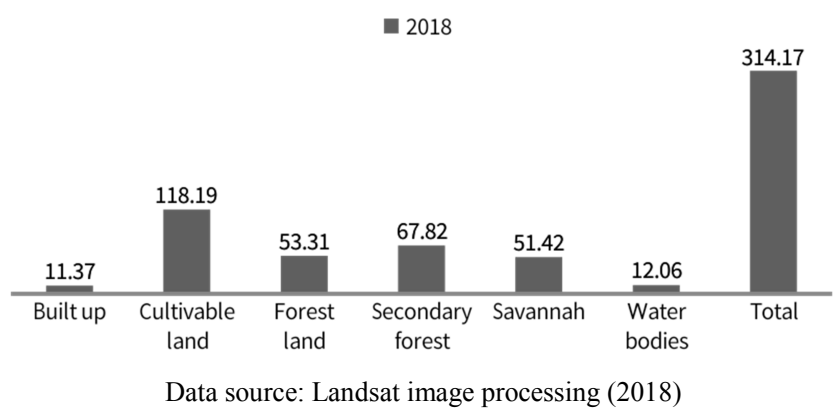

Figure 8. Land resources cover stock for 2018 (figures are in Kilometres square).

This slight increase and decrease respectively in the aforementioned resources is blamed on rapid population growth, increasing pressure on the resources and the need to reconcile regeneration-protection-conservation and food security link.

The number of degraded lands reduced even though with the expansion of the build-up area. The drop in forest land is blamed in harnessing of the Lake Oku area through the 
construction of lodging and other modern touristic facilities and the tarring of the Ndop-Oku road through the forest between 2012 and 2016 which was marked by severe deforestation for the realisation of these development projects. The slight increase in build-up area is due to the Councils involvement in controlling the building of these houses. The respect of the role of law was restored due to the change of traditional leadership as of 2007. According to the Sub-Divisional Delegate of forestry and wildlife for Oku, there are 6 forest guards in the Kilum forest zone compared to only one between 1994 and 2010. People became more sensitised through the media. Today the Council, the palace, manjong groups, FMIs, NGOs and village development institutions are very actively involved in LRs regeneration in the Oku-Mbessa Highlands.

\subsection{Sustainability and Positive Patterns Ushered in by Trends in Land Resource Management}

The concept sustainability was coined in an Earth Summit in Rio del Janerio (Brazil) in 1987. According to the Brunt land Report, sustainability means meeting the needs of the present generations without compromising the chances of the future generations from meeting their own needs [14]. According to the MNS Encarta (WWW), the word "sustainable" means able to maintain. Sustainability is a process suggested to improve the quality of human life within the limitations of the global environment. The environment here represents resources as a precondition for a decent life. This will make environmental resources not to always be depleted but will always exist for use [23]. The LRM trends have been a mixed blessing in this highland area. Positive patterns have been introduced by these trends reflected on livelihoods and environmental benefits. This has addressed the problems of livelihood diversification and environmental degradation.

Ensuring food security and diversification of livelihoods opportunities

Assessing environmental protection and food security link in the Oku Mbessa Highlands show that there has been a serious challenge in maintaining conservation and at the same time ensuring food security. However the coming of NGOs, councils and other partners in to the scene of LRM in the OMHs has ensured food security in comparative terms with previous periods before 1982. According to the statistics from the Elak council, $80 \%$ of the population have two meals a day as of $2010 ; 60 \%$ of the farmers as from 2005 increasing their yields by $5 \%$ supported by the council; $20 \%$ of farmers practicing sustainable farming; $20 \%$ reduction in crop loss; 705 farmers using improved seeds; 50\% using organic manure and $60 \%$ farming groups functioning well. Many crops are being cultivated. These crops generate a lot of income to the farmers which go a long way to help them in the livelihood endeavors (table 4).

Ninety four percent of the population agreed that resource exploitation is a source of livelihood through agriculture, $4 \%$ disagreed and $2 \%$ were neutral. The resource like the forest reserve is a typical source of rural alternative food supplements to inhabitants of the neighbouring villages. Soil resources provide variety of food products. Agrarian resource management provides livestock which is a source of protein and income to the population. Hydrological resources provide livelihood opportunities through the supply of portable water, and the recent bottling and commercialisation of the Kilum montane water by some stakeholders.

Table 4. Crops and estimated prices in the Oku-Mbessa Highlands.

\begin{tabular}{lll}
\hline Crop & $\begin{array}{l}\text { Average annual harvest per } \\
\text { farmer in } 20 \text { litres buckets }\end{array}$ & $\begin{array}{l}\text { Price per 20 litres } \\
\text { bucket in FCFA }\end{array}$ \\
\hline Beans & 7 & 5000 \\
Maize & 13 & 2000 \\
Potatoes & 30 & 700 \\
Cocoyam & 10 & 3000 \\
Tomatoes & 7 & 4500 \\
\hline
\end{tabular}

Source: [24]

\section{Portable water accessibility}

The Kilum mountain forest reserve acts as a water shed anchored on the top of volcanic rocks where many rivers from Oku take their rise such as Emfve, Miih, Emfuoy, Ndah, and Lang. There are also a multitude of springs that have been harnessed by the adjacent villages to supply community drinking water. Villages with community water projects harnessed from the forest catchments are Manchok which is the largest, Simonkoh, Mbockenghas, Tankiy, Ngvuinkei II, Ngashie, Keyon, Jiyane, and Kevu. The mountain region does not only supply water to the neighbouring adjacent communities but to other distant areas like Ntowel, Kfwi, Fekeng, and Bow. These villages get this portable water directly from the montane forest through a community understanding for the extension of nearby water schemes from the forest to their communities. This the case of the village of Ntowel that is currently using pipe borne water extended from the Simonkoh water scheme. Community members provide funds and human resources for the success of their water schemes just like the Chiangka quarter water scheme started in 2015 and completed in 2017 whereby each man was to pay $10000 \mathrm{fcfa}$, women $5000 \mathrm{fcfa}$ and all children of secondary school going age paying $1000 \mathrm{fcfa}$. All the members were also expected during this period to provide human labour for 6hours every week or pay a fine of $2000 \mathrm{fcfa}$.

\section{Biodiversity conservation}

The sustainable management of resources through combating desertification, fighting climate charge and controlling pollution as an environmental protection strategy have help seriously in the conservation of biodiversity. Sampling from the population also show that 405 of all the grazers practice proper grazing through fencing and generating grass and $20 \%$ increase in biodiversity conservation. The actions of NGOs like CAMGEW, SOPISDEW (table 1), OREP and the council has protected a lot of floristic and fauna resources. The red listed Newtonia Camerunensis a native plant has been rescued by the management activities in 2017. The Barnemanns turaco has also been saved from the havoc of the hunters. This is 
contrary to the views of [26] who concluded that biodiversity loss is consistently exaggerated in the Eastern slopes of Mount Oku. Varieties of animal species have been introduced and reared in efforts to conserve animal species as seen in table 5 .

Table 5. Categories of livestock reared in the Oku Mbessa highlands.

\begin{tabular}{ll}
\hline Livestock & Number \\
\hline Cattle & 1700 \\
Goats & 9230 \\
Sheep & 6975 \\
Horses & 101 \\
Donkeys & 5 \\
Dogs & 216 \\
Pigs & 1600 \\
Cats & 215 \\
Fish & 520 ponds \\
Fowls & 10285 \\
Rabbits and Guinea pigs & 413 \\
Total & 31260 \\
\hline
\end{tabular}

Source: [27]

Goats and sheep are the highest because all the natives of $\mathrm{Oku}$ and Mbessa practice the open free rage system of rearing these animals. Cattle are mostly kept by the migrant Fulani who do not have a permanent piece of land to practice the keeping of these animals. Donkeys and horses are the least because the indigenous people of the OMHs are not into the tradition of keeping this livestock as they have significance their cultures.

\section{Creation of employment opportunities}

Field surveys indicate most of the population in favour of the fact that livelihoods and employment are benefits accrued from the trends of LRM practices. Evidence from field statistics show that $20 \%$ jobs in the OMHs are created from the management and exploitation of local resources and $20 \%$ of the population increasing their revenues by $10 \%$. Tree nursing and planting has strong relationship with income generation. Workers paid to take care of young planted trees, workers paid to plant trees and those transporting tree seedlings for planting involving, workers employed to work in the nurseries are paid. The payment of workers on tree planting started right in the 1990s with FMIs workers paid by Birdlife International and KIMFP who were in charge of managing the forest. These FMIs created jobs as workers were recruited to take charge of the forest management. Catchment and water scheme managers are also paid for this job. Tourist guides are also paid.

All these create jobs; talking less of almost all the natives who depend on farming as they are employed and supported by these activities. This is because in the recent past decade, Irish potatoes and market gardening products in addition to cash crops like coffee have farmed mainly for the rural and urban markets. Local craft groups also create employment through the artifacts produced from the forest products. Caretakers of resources are reinforced by employment of guards like forest guards. In addition to the direct employment opportunities analysed above, indirect employment aspect of the forest can also be analysed.
Workers employed in honey cooperatives sustain their livelihoods by working in these cooperatives though not directly involve in forest exploitation. As a source of traditional pharmacopeia, herbalists are employed and make a living from these resources.

\section{Promotion of ecotourism and tourism}

Touristic sites have been widely protected in the OMHs. According to the Elak Council, 100 tourist visit Oku every year and the council successfully developing 10 natural sites by 2012 . The most prominent are the picturesque volcanic Lake Oku, the mountain itself $(3011 \mathrm{~m})$ and volcanic scenery some waterfalls, the forest reserve laden with animal and plant species (some of which are found nowhere else in West Africa), a biodiversity with countless options of modern and traditional research as well as endemic plant and bird species. Tourists visit these touristic hotspots in this area from Cameroon and other continents in the world.

Between the year 2002 and 2014 two museums were created in Oku captioned as Oku Cultural and Touristic Centre (OCUTOC) created in 2002 and Oku Fon's Palace Museum. These museums are institutional epitomes of sociocultural values and community development that educate the local people by intergenerational representational strategies, symbolic representation, stimulation of local craft and creative industry and as well as open up the community to the entire world through tourism.

Disenclavement of resource sites

About $50 \%$ of resource sites are accessible. The management of LRs in the OMHs brought in many partners who were also interested in disenclaving the inaccessible resource sites. This is the case of the French government in Cameroon that tarred the Ndop-Oku road to disenclaved the Kilum montane forest and Lake Oku. The Council's involvement has led to the development of motorable roads to areas where such a road has never existed until the Council road works in 2018. This is the case of the Mbulum-EbkwakNtowel-Lum road in the Mbai zone constructed in April 2018.

\section{Greater environmental awareness}

LRM activities have contributed greatly to sensitisation on best practices on the environment. The government, internal and external partners through bulletins, newspapers, trainings, media and sign post have been reaching a wide audience in this area with a common message on best environmental practices. This, among others started long ago with traditional notables. A point in case is a traditional notable Fai Mankoh once village head of Ngashire and chairman of the traditional council of Oku have always in his outreach to the population passed a common message to the population by saying “....let's protect our land especially the forest and Mawes (Lake Oku)........ We should know among other things that if Mkong-Moteh is the father of Oku, then obviously the forest is the mother of Oku. I don't think a person can be killing his or mother with his or her own hands" [29]. Greater awareness saw the light of day when CAMGEW and SOPISDEW started since 2015 to extend their activities of sensitisation the primary and secondary schools. SOPISDEW for example have been involved in 
sensitisation and introduction of agro-forestry schemes and tree nurseries in GBHS Tolon and GSS Mboh in 2014 and CAMGEW in a similar exercise in GS Bow in 2016 [18].

\section{Discussion of Results}

There has been the reinforcement of resource sustainability through multi-sectorial and multi-stakeholder participation by protecting and conserving the resources hubs. Fieldwork statistics portray $80 \%$ of LRM activities as environmentally responsive, accountable for the diminution in resources degradation by $82 \%$ with $70 \%$ of the population practicing sustainable resource management activities as echoed in many cases $[15,16,20]$. This has ushered in optimistic signatures in the stocks of these resources with forest land protrusion from $37.06 \mathrm{~km}^{2}-44.76 \mathrm{~km}^{2}$. Management has been crewed by regeneration and environmental protection endeavours, surmounting the anthropogenic pressures placed on these forest lands $[21,22,31]$. The ultimate outcome has been the compromise between sustainability and ever increasing livelihood anxieties of indigenous communities $[25,32]$. This is in defiance to [14] who saw only $30 \%$ of resource management activities in Cameroon and many parts of the world as environmentally friendly, amplifying resource degradation [17-19] by indigenous stakeholders who solely depend on these resources for survival in mountainous communities. Field veracities also portray a drop in NGOs activities in 2018 blamed on insecurities triggered by the socio-political crisis in the Anglophone parts of Cameroon. However, the Oku-Mbessa highlands resources management sustainability have consecrated these mountainous lands myriad of natural and human touristic potentials [19, 28], environmental awareness [30] and research potentials.

\section{Conclusion and Recommendations}

LRM in the OMHs is marked by the dynamic trends of multi-stakeholders and their management activities and interests also vary [33]. The general tendency in these trends is a significant increase in the management processes. This increasing trend is more apparent in Oku than in Mbessa. These mutations in management strategies have greatly ushered in remarkable positive changes in land cover, land use and the general land resources stocks portraying a general increase in livelihood opportunities and environmental sustainability. The F-ratio analysis at a 0.05 critical level and a df of 4 reveals ratios of (1.094), (1.210) and (2.053) are more than the tabulated ratios of $0.361,0.308$ and 0.088 for 1982-1994, 1995-2006 and 2007-2018 respectively. This results validates the hypothesis and it can therefore be concluded that the trends of land resource management has been experiencing an increasing development from 1982-2018. These trends have had varied significant positive implications reflected on livelihoods diversification and environmental sustainability in the Oku-Mbessa highlands as seen in other parts of the world.
Considering the inextricable link between LRs and livelihoods, the study recommends local coordination efforts to be stepped up to restrict further encroachments into the protected resource hotspots like the Kilum/Ijim Montane. This should begin with the enforcement of the laws. Technical and financial support from the state should be boasted that will go a long way to improve on the situation of LR conservation. Partnerships between the government and other conservation organisations should be strengthened to coordinate interventions to improve resource protection, afforestation, bee keeping and training of local community groups on improved farming methods.

This study also recommends the need for the government and council authorities to improve governance and security at the grassroots levels to forestall individuals taking laws into their hands in events of LR dispute and breaking established LRM laws. They should do this by beginning with sensitisation of the indigenous people to mobilise themselves and be aware on the need for them to be law abiding and to shun all forms of environmental degradation in exploitation and violence in any situation of village inter and intra-ethnic misunderstandings over LRM issues. This will be fundamental to addressing land resources management grievances and conflicts as a tool to creating resource sustainability and peace. In this context, international assistance should prioritised by these authorities.

\section{References}

[1] Aghileri D. and Burlando P. (1999) Water resource management. Report on the EU water framework on the threshold: environmental changes as causes of acute conflict. Journal of international security. Vol. 16, No 2 (Fall 1999), pp. 76-116. 2017.

[2] IUCN (2013) Report on Bangladesh national conservation strategy of land resources.

[3] UNO (2013) Economic contributions of forests. UN forum on forests. $10^{\text {th }}$ session. $8^{\text {th }}-9^{\text {th }}$ April 2013, Istanbul, Turkey.

[4] Annbee T, (2016) Conservation, Protection \& Rehabilitation of the Environment \& Natural Resources. Journal of sustainable development. Vol. 7, No. 9; ISSN pp. 1916-1927.

[5] Robbin G., Man-Kwan C., Julia A. and Julian Q. (2008) Trees and trade off: A stakeholder approach to natural resource management. Gate keeper series No 52.

[6] World Bank (2006) Sustainable Land Management challenges, opportunities and trade-offs. 1818 H Street, NW Washington, DC 20433.41p.

[7] EU (2015) Framework Service Contract for the operation, evaluation and evolution of the Global land Component of the Copernicus Land service-4 Lots JRC/IPR/2015/H.5/0026/OC. Ref. Ares (2015) 3305485.

[8] Noubissie T. D. (2012) The concept of sustainable development and sustainable management of natural resources in Africa through the German Development Corporation". Doctorate Thesis. University of Giessen Germany. 
[9] Talus T. (2016) Identifying stakeholders in land use management process and related critical factors in ASEAN". ASEAN and Canada research partnership working paper series No 1 .

[10] EU and UN (2012) Land and Conflict: Toolkit and guidance for preventing and managing land and natural resources conflict" New York.

[11] CIRUM (2012) Customary laws in forest use and management. Case study among the Dzao and Thai people of North West Vietnam. Available at www.cirum.org. Consulted in September $24^{\text {th }} 2018$.

[12] Babuh U. M. S. Nautiyal S. (2013) Historical issues and perspectives of land resource management in India. A review of the institute for social and economic and social change, Bangalore, working paper series 309. ISBN 978-81-779-1657.

[13] Mengang J. M. (1994) Evolution of natural resource policy in Cameroon, Ministry of Water and Forests BP 13844, Yaoundé, Cameroon. $\mathrm{N}$ bulletin 102

[14] Ndenecho E. N. (2005) Biological resource exploitation in Cameroon. From crisis to sustainable management. Unique printers Bamenda.

[15] Elak-Oku and Belo Council Development Plans (2017) Elaborated with the support of the National Community Driven Development Program (PNDP).

[16] Kimengsi J. N. and Moteka P. N. (2018) Revisiting Participatory Forest Management and Community Livelihoods in the Kilum-Ijim Montane Forest Landscape of Cameroon. International Journal of Global Sustainability ISSN 1937-7924 2018, Vol. 2, No. 139. pp. 39-55.

[17] Wirsiy E. B. (2018) CAMGEW annual report from 2012 2018”. 164p.

[18] Tah K. K. (2018). "SOPISDEW annual reports from 2012 to 2018". 77 p.

[19] Ndenecho E. N. (2006) "Sustaining mountainous environments and rural livelihoods in the Bamenda highland of Cameroon". Unique printers Bamenda.

[20] Raymond A., Wilson A. A., Michael J C and Stephen A. (2017). "Multi-level land cover change analysis in the forestsavannah transition zone of the Kintampo Municipality, Ghana". Journal of Natural Resources and Development; VOL 07, No 01, pp 1-11. May. 2017. DOI: 10.5027/jnrd.v7i0.01.

[21] Yude P. and Richard B. (2018). "Trends in management of world's forests and impacts on carbon stocks". Journal of forest ecology and management. Vol. 355 pp. 83-90. 2015. Available at www.slsevier.com. Consulted on September $20^{\text {th }}$ 2018.
[22] Espírito-Santo M. M., Leite M. E., Silva J. O., Barbosa R. S., Rocha A. M., Anaya F. C., Dupin M. G. V. (2016). "Understanding patterns of land-cover change in the Brazilian Cerrado from 2000 to 2015," Philosophical Transactions of the Royal Society B: Biological Sciences, vol. 371, no. 1703, pp. 20150435, Aug. 2016. Doi: https://doi.org/10.1098/rstb.2015.0435

[23] World Bank (2003). "World Development Report 2003: Sustainable Development in a Dynamic World". The World Bank, Washington, DC. 2003.

[24] Sub-Divisional Delegation of Agriculture and Rural Development Oku Sub-Division (2017).

[25] Fogwe Z. N. and Kwei J. (2015). "Cameroonian protected Kilum Ijim Forest for the development of Oku forest fringe communities". E3 Journal of resource and Environmental Management; Volume 6 (5) PP. 0293-0303, December, 2015. http://www.e3journals.org ISSN 2141-7466.

[26] Chah R. (2014). "Forest degradation and its Implication on the Slopes of Mount Oku". DIPES II Dessertation, Geography Department, HTTC University of Bamenda North West Region of Cameroon. 2014. Unpublished.

[27] Sub Divisional Delegation of Livestock Fisheries and Animal Husbandary Oku Sub-Division (2017). "Annual Report on Pastoral Activities (2012) Sub-Divisional Delegation of Livestock Fisheries and Animal Husbandry Oku”. 41p.

[28] Tambang G. N. (2009). "Wood carving in Oku: An economic activity in expansion", DIPES II Dissertation in Geography, ENS Yaounde.

[29] VOKIMF magazine February 1997 edition.

[30] Nkongho P. E. (2001)."Land use variations and vegetation changes in the Falgore game reserve area, Kano state Nigeria". Readings in Geography. Unique printers Bamenda. Pp 222-235.

[31] Mugambi D. M. (2019). Fencing and Forest Conservation: Attitudes of Local People Living Adjacent to Eastern Slopes of Mount Kenya. International Journal of Natural Resource Ecology and Management. Vol. 4, No. 1, 2019, pp. 1-6. doi: 10.11648/j.ijnrem.20190401.11.

[32] Jean S. N. and Yves M. T. (2019). Livelihoods Means and Local Populations Strategies of the Luki's Biosphere Reserve in Democratic Republic of Congo. International Journal of Natural Resource Ecology and Management. Vol. 4, No. 2, 2019, pp. 42-49. doi: 10.11648/j.ijnrem.20190402.12.

[33] Bailack K. M. and Fogwe Z. N. (2019). Land resource conflict mitigation diplomacy for harmonious inter communities coexistence: the Oku-Mbessa legacy in the North West region of Cameroon. International Journal of Current Research, Vol. 11, Issue, 07, pp. 5628-5635, July, 2019. DOI: https://doi.org/10.24941/ijcr.35494.07.2019 